\title{
Epidemiology of Group A Rotavirus Diarrhea among Children Hospitalized for Acute Gastroenteritis in Ondo State, Nigeria
}

\author{
Michael Oluyemi Babalola ${ }^{1,2}$ David Olufemi Olaleye ${ }^{1}$ \\ ${ }^{1}$ Department of Virology, Faculty of Basic Medical Sciences, College \\ of Medicine, University of Ibadan, Ibadan, Nigeria \\ ${ }^{2}$ Department of Microbiology, Division of Infectious Diseases \\ Epidemiology, Virology and Special Pathogens Research, Adekunle \\ Ajasin University, Ondo State, Nigeria \\ J Child Sci 2021;11:e338-e349.
}

Georgina Njideka Odaibo ${ }^{1}$

\begin{abstract}
Address for correspondence Michael Oluyemi Babalola, PhD, Department of Microbiology, Division of Infectious Diseases Epidemiology, Virology and Special Pathogens Research, Adekunle Ajasin University, P.M.B. 001 Akungba Akoko, ZIP 432111, Ondo State, Nigeria (e-mail: michael.babalola@aaua.edu.ng).
\end{abstract}

\begin{abstract}
Keywords

- diarrhea

- RVA

- epidemiology

- children

- Ondo state

- Nigeria

Globally, infective group A rotavirus (RVA) enteric infection in children culminates in acute diarrheal disease, severe dehydration, and mortality in children under the age of 5 years, particularly in sub-Saharan Africa. This research sought to determine the prevalence of RVA diarrhea among children aged below 5 years in Ondo state, as one of the necessary frameworks before instituting a vaccine campaign, and to expand knowledge on the epidemiology of RVA diarrhea in Nigeria.

In a cross-sectional descriptive study between October 2012 and September 2014, convenience sampling was adopted to obtain demographic information, clinical details, and stool samples from accented under five children who sought treatment for acute gastroenteritis at designated hospitals in Akure and Owo, Nigeria. A total of 390 stool samples were collected from children with acute diarrhea and tested for VP6 RVA antigen using enzyme immunoassay. Data generated were analyzed using descriptive statistics and chi-square at $\alpha_{0.05}$.

From the 390 children hospitalized for diarrhea, 240 samples (240/390; 61.5\%) were from males, while 150 samples (150/390; 38.5\%) were from females, representing a male:female ratio of 1.6:1. RVAs were found in 24.2\% (58/240) males and 28\% (42/150) females, giving a male-female ratio of 1:1.2 and total prevalence of $25.6 \%$ (100/390). RVA infection was inversely proportional to the age as a rate of $11.8 \%$ was observed in children aged above 36 months and $31.8 \%$ (35/110) in children 7 to 12 months, while the highest rate $(45.7 \%)$ was among children $\leq 6$ months old. No significant difference was found (chi-square $=0.712$ ) in the induction of diarrhea in children from Akure and Owo, neither was there any significant difference in the rates of infection between the boys and girls in Akure (chi-square $=0.576$ ) nor in Owo (chi-square $=0.333$ ). Seasonal association (chi-square $=5.802$ ) in RVA infection was observed in the rainy season of year 2013/2014 period.

RVA diarrhea occurred year-round at a prevalence of $25.6 \%$, predominantly in females. A seasonal fluctuation was observed in the rainy and dry seasons of the 2-year period. RVA diarrhea occurred predominantly in children aged below 18 months of age, and may thus help in determining the optimal period/schedule of any immunization program.
\end{abstract}

received

May 30, 2020

accepted

August 17, 2020
DOI https://doi.org/

$10.1055 / \mathrm{s}-0040-1718543$.

ISSN 2474-5871. (c) 2021. The Author(s).

This is an open access article published by Thieme under the terms of the Creative Commons Attribution License, permitting unrestricted use, distribution, and reproduction so long as the original work is properly cited. (https://creativecommons.org/licenses/by/4.0/)

Georg Thieme Verlag KG, Rüdigerstraße 14, 70469 Stuttgart, Germany 


\section{Introduction}

Structurally, rotaviruses (RVAs) are $70 \mathrm{~nm}$ nonenveloped ribonucleic acid (RNA) virus of the family Reoviridae. The icosahedral nucleocapsid is composed of three concentric shells, comprising an innermost core, the middle layer, and an outer capsid enclosing 11 segments of double-stranded RNA genome. The RNA genome segments encode six structural proteins (VP1, VP2, VP3, VP4, VP6, and VP7) and six nonstructural proteins (NSP1, NSP2, NSP3, NSP4, NSP5, and NSP6) that are found in infected cells. ${ }^{1}$ The outermost shell contains two structural proteins: the VP7 (this glycosylated protein G capsid is the most abundant of the two) and the protruding VP4 (the protease-cleavable, P-protein viral hemagglutinin consisting of only 250 molecules per rotavirion). The VP7 is encoded by gene segment 7,8 , or 9 , depending on the strain, while VP4 is encoded by gene segment 4 . The two proteins define the serotype of the virus and are critical to vaccine development as they independently elicit type-specific and cross-reactive neutralizing antibody responses. ${ }^{2}$ Based on their distinct antigenic and genetic properties derivable from the middle capsid protein VP6, the genus Rotavirus is presently classified into 10 groups (A, B, C, D, E, F, G, H, I, and J) including rotavirus I, recently identified among dogs in Hungary and rotavirus J among bats in the Republic of Serbia. ${ }^{3,4}$ Human infection has been reported with groups $\mathrm{A}, \mathrm{B}$, and $\mathrm{C}$ RVAs. In contrast, other groups have been found only in animals. ${ }^{5}$ Among these, group A Rotaviruses are known to exhibit the highest prevalence, pathogenicity, high burden of severe acute diarrhea disease, and mortality of under-five children in sporadic and epidemic gastroenteritis around the world. ${ }^{6,7}$ RVA accounts for 25 to $50 \%$ of all hospitalizations of children for diarrhea in both developed and developing countries, with African regional prevalence range of 39 to $52 \%$ and global deaths of 453,000 children in year $2008 .{ }^{8,9}$ As of 2016, RVA was the third leading pathogen associated with mortality among those younger than 5 years, and the RVAassociated mortality rate was highest in sub-Saharan Africa, Southeast Asia, and South Asia, of which a total of 104,733 deaths occurred among those younger than 5 years in subSaharan Africa. ${ }^{10}$ The infant mortality in Nigeria is overwhelming as 1,043,000 deaths of children aged below 5 years were reported out of 5,377,000 births annually and this was corroborated by Parashar et al that approximately 50,000 infantile deaths occurred in Nigeria as a result of RVA diarrhea. ${ }^{8,11}$ Global estimates indicated that India, Congo (DR), Pakistan, as well as Nigeria contributed almost $49 \%$ of the global infant death as a result of RVA diarrhea in year 2013. ${ }^{12}$ Yet, RVA immunization has not been implemented as part of the Expanded Program on Immunization in Nigeria and several African nations, to combat this ubiquitous disease of childhood.

The Centers for Disease Control and Prevention recommended gathering and sharing data on the epidemiology, seasonality, and identification of circulating RVAs to identify critical needs for effective vaccine development for diverse human environments. ${ }^{13}$ In a hospital-based prospective study, the prevalence of RVA infection was 35\% among children aged between 0 and 5 years in Lagos state, while in separate studies in Benin City, Nigeria, a decrease in prevalence from $39.4 \%$ in 1989 to $19.2 \%$ in 2015 was reported. ${ }^{14-16}$ There is currently a paucity of data on rotaviral infantile gastroenteritis in Ondo state of Nigeria, where diarrhea illness is a significant contributor to the hospitalization and mortality of infants, where the level of sanitation is low, the residents utilizes rainwater, shallow wells, and streams for domestic use/consumption. ${ }^{17}$ This study specifically sought to detect RVAs from under-five children with gastroenteritis, to determine the risk factors, the clinical characteristics, the prevalence of RVA diarrhea, to compare the rate of infection between the males and females within age groups and locations, and to determine the seasonal trend or pattern (if any) of RVA diarrhea disease in Ondo state, Nigeria, as part of baseline data for immunization purposes in Nigeria.

\section{Methods}

\section{Study Area: Akure and Owo, Nigeria}

Ondo state is one of the six states in southwest Nigeria, with a population of $3,441,024$ of which under 5 years children were $13.5 \%$, while the number of live births was 154,016 , and according to the State Health Policy, the infant mortality rate is 70 per 1,000 live births. ${ }^{18,19}$ Ondo state has typically tropical climate with alternating wet and dry seasons (April-October and November-March, respectively). The State Bureau of Statistics reported in 2012 that with regards to toilet facilities, $43.5 \%$ of households in the state dispose their fecal wastes in unhygienic ways. About $39.8 \%$ of the households depend on protected well/spring for drinking and cooking, $28 \%$ relied on boreholes, $8.5 \%$ on treated pipeborne water, and so on. The state has four specialist hospitals and two tertiary health care facilities (the Federal Medical Centre Owo and UNIMED Teaching hospital). Local Government Areas have government managed secondary hospitals and primary health care units, while private clinics also provide health services to the population. ${ }^{20}$ The study locations were Akure and Owo. Akure, the state capital lies approximately $7^{\circ} 25^{\prime}$ north of the equator and $5^{\circ} 19^{\prime}$ east of the Meridian. It is approximately $700 \mathrm{~km}$ southwest of Abuja and $311 \mathrm{~km}$ north of Lagos state; Owo, the headquarter of Owo Local Government lies on latitude $7^{\circ} 11^{\prime} \mathrm{N}$ of the equator and longitude $5^{\circ} 33^{\prime} \mathrm{E}$ of the Greenwich Meridian (-Fig. 1).

\section{Study Design and Study Centers}

This study was a hospital-based, cross-sectional, descriptive study, aimed at determining the prevalence of RVA diarrhea among children with gastroenteritis in Ondo state, Nigeria, within two Rotavirus seasons. This multicenter clinical study was conducted by recruiting under-five children who sought treatment for gastroenteritis at general hospitals, the pediatric departments of the Federal Medical Centre, Owo, the State Specialists Hospital Akure, and the Mother and Child Hospital, Akure. The centers were selected based on availability of the specified population, the ability of the facilities to handle severe disease/admission, and localization of a Government hospital specifically established to cater for health care of children and nursing mothers. 


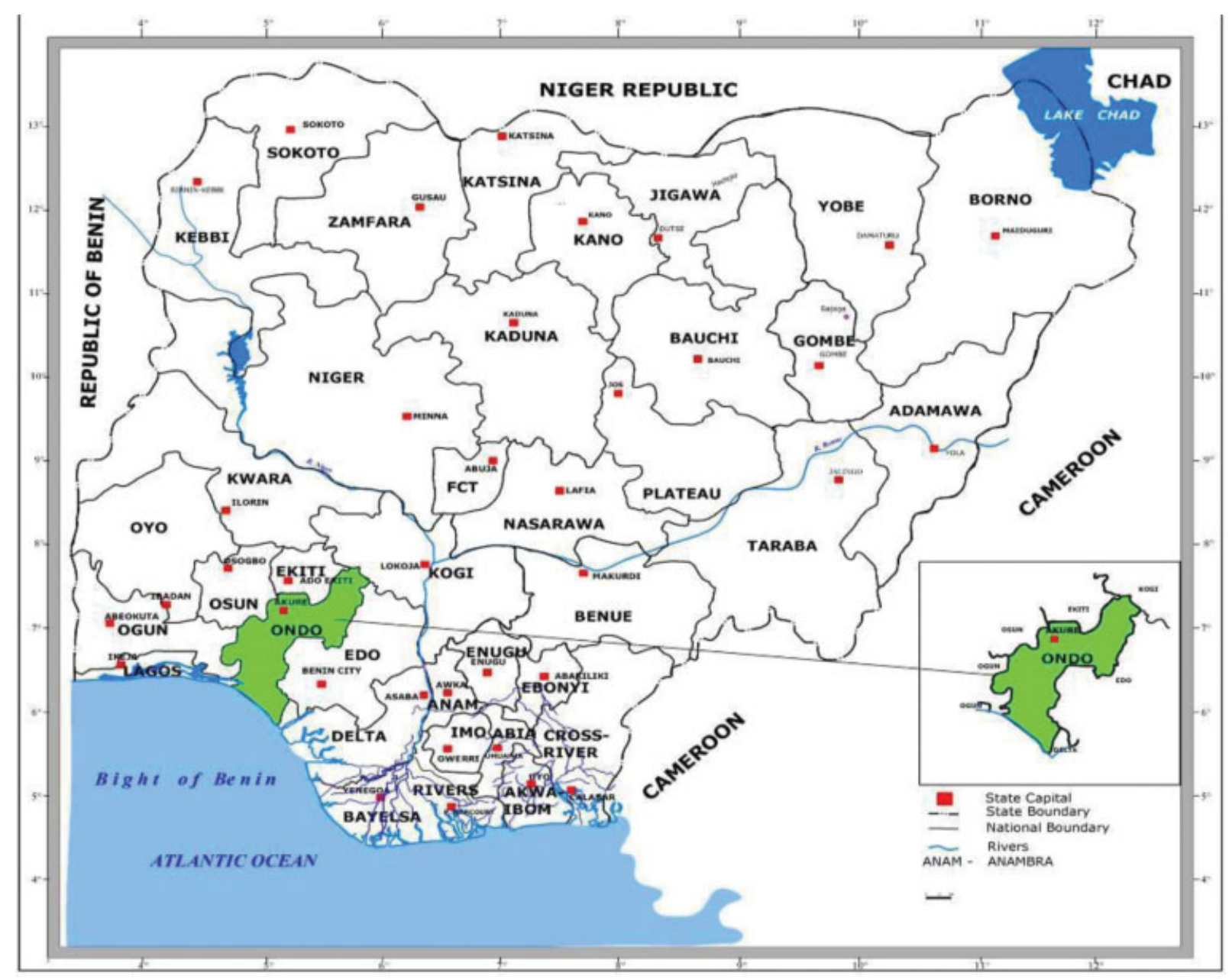

Fig. 1 Map of Nigeria showing Ondo state, the study area.

\section{Study Population and Sampling Method}

Infants and young children aged between 0 and 5 years who presented to the outpatient clinics or placed on hospital admission at the designated hospitals for acute diarrheal illness, between October 2012 and September 2014 were recruited. Convenience sampling was adopted in collecting stool specimens, 1 to 3 days after the onset of the disease, from the children who satisfied the inclusion criteria and presented to the hospital with acute diarrheal illness.

\section{Criteria for Inclusion and Exclusion of Participants}

Children under 5 years of age who presented with acute diarrhea, having experienced evacuation of loose, watery stools, three or more times in 24 hours as reported by the parents. Children with diarrhea that lasted for $\leq 7$ days were included since studies have shown that the incubation period for RVA illness is less than 48 hours and usually will last for 5 to 7 days. ${ }^{21}$ Children above 5 years of age, or with bloody diarrhea, or with diarrhea that lasted more than 7 days, or prospective participants whose parents declined consent were regarded as ineligible and excluded.

\section{Sample Size Determination}

From a previous study, a prevalence of 35\% was reported for RVA infection in Lagos state. ${ }^{14}$ Using the formula: $n=Z \alpha^{2} P q / d^{2}$.
Where $n=$ sample size; $Z \alpha=$ standard normal deviation corresponding to $5 \%$ level of significance $(1.96)^{2} ; P=$ prevalence of outcome of interest (35\%); $d=$ level of precision (5\%); $q=1-P$. Substituting in the formula,

$$
\begin{aligned}
\mathrm{n} & =(1.96) 2 \times 0.35(0.65) /(0.05) 2 \\
& =3.8416 \times 0.2275 / 0.0025 \\
& =0.873964 / 0.0025=350
\end{aligned}
$$

The sample size was increased to 385 to accommodate for $10 \%$ attrition rate. Thus, it was calculated that 385 samples would be necessary to achieve the required sufficient precision for the study. However, a total of 390 samples were available and utilized for this research.

\section{Ethical Considerations}

This study was approved by the University of Ibadan (UIUCH) Institutional Review Board and permission was granted by the respective Ethical Committee of the study center. Informed consent was obtained from the parent/ guardian of the participating children before sample collection. Patient's anonymity was maintained, data generated were confidential, and used only for this research. 


\section{Demographics and Clinical Factors}

At the time of recruitment and admission of the participants to the hospital, the severity of diarrhea and demographics were determined. The parents were interviewed using a structured questionnaire to obtain demographic information and clinical factors associated with RVA diarrhea. These included parents' education/employment, the participants' age (months), the gender, sources of drinking water, feeding practices, duration of diarrhea before hospitalization, stool characteristics, frequency of diarrhea, severity of diarrhea such as vomiting, dehydration requiring intravenous rehydration, antibiotic administration, and the manifestation of upper respiratory tract infection (URTI).

\section{Collection of Samples and Detection of Rotavirus Antigen Using Lateral- Flow Enzyme Immunoassay}

During diarrhea episode, one fresh stool specimen was collected once per child in clean, screw-capped tubes, labeled, and immediately stored frozen, prior to transportation on ice to the Virology Department, University of Ibadan Nigeria, for testing. The stool specimens were tested for the presence of RVA by detecting the VP6 antigen, using a 4th generation Quadruple Immunochromatographic Combo enzyme immunoassay according to the manufacturers' instructions (Certest, Zaragoza, Spain) and as previously reported by Babalola et al. ${ }^{22}$ The results were then recorded.

\section{Statistical Analysis and Presentation}

Data obtained were recorded in Microsoft Excel and analyzed using descriptive statistics as shown in percentages, mean, median, and ratios. Inferential analysis and infection proportions were tested for statistical significance by the use of the chi-square test and used to compare groups. Differences were considered statistically significant if $p \leq 0.05$.

\section{Results}

\section{Demographics and Clinical Characteristics of Under 5 Years Children Hospitalized with Acute Rotavirus Diarrhea in Ondo State, Nigeria}

This study population consisted of 390 eligible under-five children who were hospitalized for diarrhea, from whom stool specimens were collected and tested for the presence of RVA infection over two Rotavirus seasons (October 2012 to September 2014). Children with watery diarrhea stool constituted the highest number of participants (92\%), while $8 \%$ were with nonwatery stool. The most common stool type was watery diarrhea from where RVA was recovered from $27.2 \%$ of cases. A significant relationship was observed in RVA shedding between watery diarrhea stool than nonwatery stool (chi-square $=5.179, p=0.023$ ). On stool characteristics, participants with mucoid stool constituted the highest number of cases (65\%) followed by children with yellowish watery stool (22\%). However, RVA was detected more frequently from watery, greenish diarrhea stool (57.7\%). A statistically significant relationship (chi-square $=67.682$, $p=0.0001$ ) was found between stool type and RVA shedding. The other prevalent clinical features observed in RVA infec- tion in this research included vomiting in $78.2 \%$ and fever in $90.8 \%$ of the cases, from where RVA was detected at a rate of 26.2 and $26.6 \%$, respectively. No significant association (chisquare $=0.254, p=0.614$ ) was found between RVA infection and vomiting, as well as RVA infection and presence of highgrade fever (chi-square $=1.675, p=0.196$ ). Abdominal cramping was reported in $33 \%$ of the participants, and RVA was detected in $25.6 \%$ at a similar rate compared with children who reported no cramps. No significant association (chi-square $=0.004, p=0.985$ ) was observed between RVA infection and development of abdominal cramps in the infected participants.

From $41 \%$ of the severely dehydrated children, RVA was detected at a rate of $25.6 \%$ compared with $25.7 \%$ in those who experienced mild dehydration and absence of dehydration, respectively. Significant association ( chi-square $=0.0001$, $p=0.999$ ) was not found between RVA infection and dehydration of the children.

Majority of the participants were fed with home-cooked meals, breast milk, and vended foods. Although the highest numbers of hospitalized cases were observed in children fed with home-cooked meals and breast milk combined (40\%), RVA infection rate was highest in children fed with homecooked meals, vended meals and breast milk combined (25.8\%), as well as in exclusive breast-fed children (25.8\%). However, no significant association (chi-square $=0.0022$, $p=0.999$ ) existed between RVA infection and feeding practices. Majority of the participants was children of traders (49\%) and civil servants (27\%) from whom the highest rate of infection (25.7\%) was detected, respectively. No significant association (chi-square $=8.598, p=0.072$ ) was found between occupation of the participants' parents and RVA infection ( $\mathbf{- T a b l e} \mathbf{1})$.

The participants who were comatose and required oxygen resuscitation were $24 \%$, from whom RVA was recovered in 20.4\%. These features were insignificantly related with RVA infection of the children (chi-square $=1.739, p=1.872$ ). Participants with URTI were found in $24 \%$, from whom RVA was detected in $20.4 \%$ of such individuals. The development of URTI was not significantly associated (chi-square $=1.739$, $p=1.872$ ) with RVA infection of the children ( - Table 2). On average, in $27.7 \%$ of children with RVA, the diarrhea lasted for 5.6 days and the mean evacuation of stool were 6.12 times per day. Vomiting lasted for a mean period of 3 days and on average the child vomited 4.5 times within 24 hours.

\section{Monthly Distribution of Stool Samples Collected and Rates of Rotavirus Infection}

The lowest numbers of stool samples collected were four in April and June 2013, respectively, during the first year of the study, while the highest number of sample (84) was collected in March 2014, in the second RVA season. Among the 390 children, RVA antigens were detected in 100 specimens. RVA infection occurred year-round with similar trend of seasonal cluster in the months of January, February, March, April, and May, as well as monthly peaks in January, April, July, August, September, and November during the 2-year period. The lowest monthly detection rate $(11.1 \%)$ of RVA was 
e342 Epidemiology of Group A Rotavirus Diarrhea among Children in Ondo State, Nigeria Babalola et al.

Table 1 Social and demographic information of under five children with diarrhea who were tested for rotavirus infection in Ondo state, Nigeria

\begin{tabular}{|c|c|c|c|}
\hline \multirow[t]{2}{*}{ Sociodemographic variables } & \multicolumn{2}{|c|}{ Rate of rotavirus detection } & \multirow[b]{2}{*}{$p$-Value } \\
\hline & Total no. tested (\%) & Total no. positive (\%) & \\
\hline Gender: Ratio = $1.6 \mathrm{M}: 1 \mathrm{~F}$ & & & 0.399 \\
\hline Male & $240(62)$ & $58(24)$ & \\
\hline Female & $150(38)$ & $42(28)$ & \\
\hline Sources of drinking water & & & 1.000 \\
\hline Surface water (stream) & $24(6)$ & $6(25)$ & \\
\hline Well water & $218(56)$ & $56(25.7)$ & \\
\hline Borehole & $8(2)$ & $2(25)$ & \\
\hline Borehole + Well water & $23(6)$ & $6(26)$ & \\
\hline Tap water & $31(8)$ & $8(25.8)$ & \\
\hline Tap water + Well water & $66(17)$ & $17(25.8)$ & \\
\hline Rainfall and water vendors & $20(5)$ & $5(25)$ & \\
\hline Feeding practices & & & 0.999 \\
\hline Food vendors & $8(2)$ & $2(25)$ & \\
\hline Home cooking & $121(31)$ & $31(25.6)$ & \\
\hline Breast milk & $74(19)$ & $19(26)$ & \\
\hline Home cooking + Breast milk & $156(40)$ & $40(25.6)$ & \\
\hline Home cooking + Food vendors + Breast milk & $31(8)$ & $8(25.8)$ & \\
\hline Occupation of respondents' parents/caregivers & & & 0.072 \\
\hline Trading & $188(48)$ & $4(2.1)$ & \\
\hline Civil servant & $105(27)$ & $27(25.7)$ & \\
\hline Subsistence farming & $12(3)$ & $6(50)$ & \\
\hline Unemployed & $12(3)$ & $6(50)$ & \\
\hline Self-employed & $73(19)$ & $15(25.6)$ & \\
\hline Age group of respondents (mo) & & & 0.000 \\
\hline $0-6$ & $70(18)$ & $32(45.7)$ & \\
\hline $7-12$ & $110(28)$ & $35(31.8)$ & \\
\hline $13-18$ & $76(20)$ & $16(21)$ & \\
\hline $19-24$ & $53(14)$ & $7(13.2)$ & \\
\hline $25-30$ & $38(8)$ & $5(13.2)$ & \\
\hline$>31$ & $43(11)$ & $5(11.6)$ & \\
\hline Total & $390(100)$ & $100(25.6)$ & \\
\hline
\end{tabular}

obtained in November and December 2013, while the highest rate $(50 \%)$ occurred in the month of September 2014, in the second RVA season (-Figs. 2 and $\mathbf{3}$ ).

\section{Distribution of Rotavirus Infection by Locations of Sample Collection}

Among the 390 participants in this study, 210 were from Akure while 180 were from Owo. RVA was detected in 73/210 (34.8\%) from Akure, and 27/180 (15\%) from Owo. More males $(131 / 210 ; 62.4 \%)$ were hospitalized for diarrhea illness than females $(79 / 210 ; 37.6 \%)$, but RVA shedding predominated in the females $(30 / 79 ; 38 \%)$ than the males $(43 / 131 ; 32.8 \%)$ in Akure. Similarly, in Owo, more males (109/180; 60.6\%) were hospitalized for diarrhea illness than the females (71/180; $39.4 \%)$ and viral shedding predominated in the females (12/ $71 ; 17 \%)$ than the males $(15 / 109 ; 13.8 \%)$. No significant difference (chi-square $=0.712, p=0.399$ ) was observed in the induction of diarrhea in children from Akure and Owo, neither was there any significant difference in the rates of infection among the boys and girls in Akure (chisquare $=0.576, p=0.447$ ) nor in Owo (chi-square $=0.333$, $p=0.564)$ (-Table 3$)$. 
Table 2 Clinical presentations of under five children with diarrhea who were tested for rotavirus infection in Ondo state, Nigeria

\begin{tabular}{|c|c|c|c|}
\hline Clinical information of respondents & Rate of rotavirus det & & \\
\hline & Total no. tested (\%) & Total no. positive (\%) & $p$-Value \\
\hline Diarrhea & & & 0.999 \\
\hline Watery stool & $357(92)$ & $97(27.2)$ & \\
\hline Nonwatery stool & $33(8.5)$ & $3(9.1)$ & \\
\hline Vomiting & & & 0.614 \\
\hline Vomited & $305(78.2)$ & $80(26.2)$ & \\
\hline No vomiting & $85(21.8)$ & $20(23.5)$ & \\
\hline Fever & & & 0.196 \\
\hline Body temperatures $\left(\geq 39^{\circ} \mathrm{C}\right)$ & $354(90.8)$ & $94(26.6)$ & \\
\hline No fever & $36(9.2)$ & $6(16.7)$ & \\
\hline Stool characteristics & & & 0.000 \\
\hline Blood tainted & $1(0.26)$ & 00 & \\
\hline Mucoid & $253(65)$ & $32(12.6)$ & \\
\hline Greenish & 52 & $30(57.7)$ & \\
\hline Yellowish & $84(22)$ & $38(45.2)$ & \\
\hline Abdominal cramps & & & 0.985 \\
\hline Cramping & $129(33)$ & $33(25.6)$ & \\
\hline No cramping & $261(67)$ & $67(25.7)$ & \\
\hline Dehydration & & & 0.999 \\
\hline No dehydration & $113(29)$ & $29(25.7)$ & \\
\hline Mild dehydration & $117(30)$ & $30(25.6)$ & \\
\hline Severe dehydration & $160(41)$ & $41(25.6)$ & \\
\hline Comatose & & & 1.872 \\
\hline Yes & $93(24)$ & $19(20.4)$ & \\
\hline $\mathrm{Nil}$ & $297(76)$ & $81(27.3)$ & \\
\hline URTI (cough/cold) & & & 1.872 \\
\hline Yes & $93(24)$ & $19(20.4)$ & \\
\hline $\mathrm{Nil}$ & $297(76)$ & $81(27.2)$ & \\
\hline Total & $390(100)$ & $100(25.6)$ & \\
\hline
\end{tabular}

Abbreviation: URTI, upper respiratory tract infection.

\section{Prevalence of Rotavirus Infection by Gender}

In this study, $24.2 \%(58 / 240)$ of males and $28 \%(42 / 150)$ females were infected by RVA, causing diarrhea in the respondents (-Table 3 ). These represent a male:female ratio of 1:1.2. Although more males were hospitalized for diarrhea, our study indicated that RVA infection was more prevalent in the females than the males. However, no significant difference existed in RVA infection of the boys and girls (chisquare $=0.7114 ; p=0.399$ ) in the state ( - Table 4 ).

\section{Prevalence of Rotavirus Diarrhea by Age Group and Overall Rate}

By age group, the highest rate of RVA infection was 45.7\% (32/ 70 ) in children aged 0 to 6 months, followed by $31.8 \%$ (35/ 110) in children between 7 and 12 months while the lowest rate was found among those aged $\geq 31$ months. The rate of infection decreases with an increase in age. RVA occurred more frequently in children aged $<18$ months with a prevalence of $32.4 \%$ (83/256) compared with $12.7 \%$ (17/134) in children $>18$ months old. Statistically, infection by RVA was significantly higher in children aged below 18 months old (chi-square $=17.97$ ) than children $\geq 18$ months old. Among the age groups, RVA infection varied significantly (chisquare $=29.666 ; p=0.00002$ ) with age groups. The overall prevalence of the circulating rotavirus infection was $25.6 \%$ $(100 / 390)$ in children below 5 years that were hospitalized because of acute diarrhea ( - Table 4 ).

\section{Monthly Distribution, Rates, and Seasonal Pattern of Rotavirus Gastroenteritis}

In the first year of the study (October 2012-September 2013), RVA infection occurred among the study participants in the 


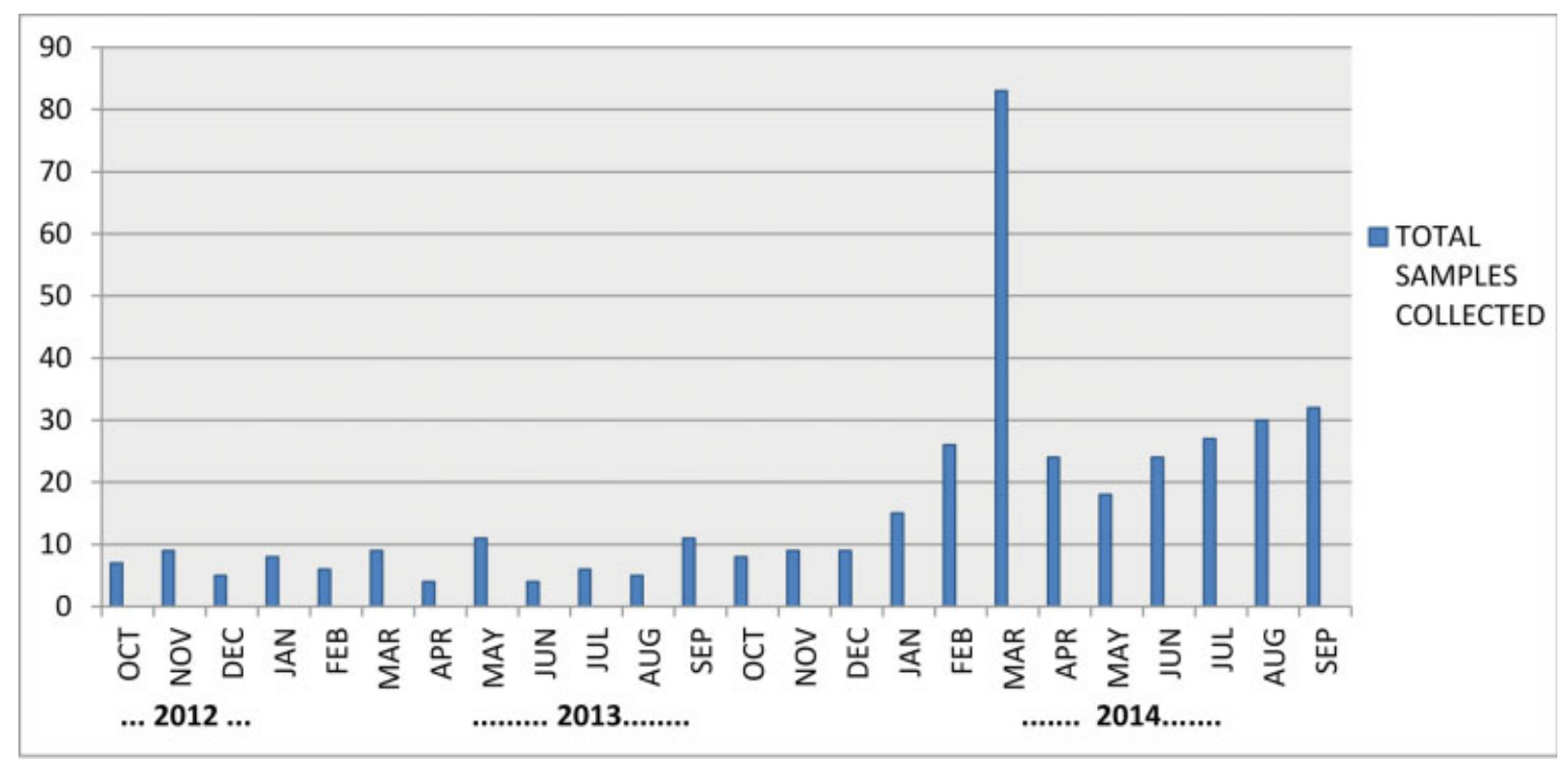

Fig. 2 Monthly distribution of samples collected from under 5 years children hospitalized of acute diarrhea from October 2012 to September 2014 in Ondo state, Nigeria.

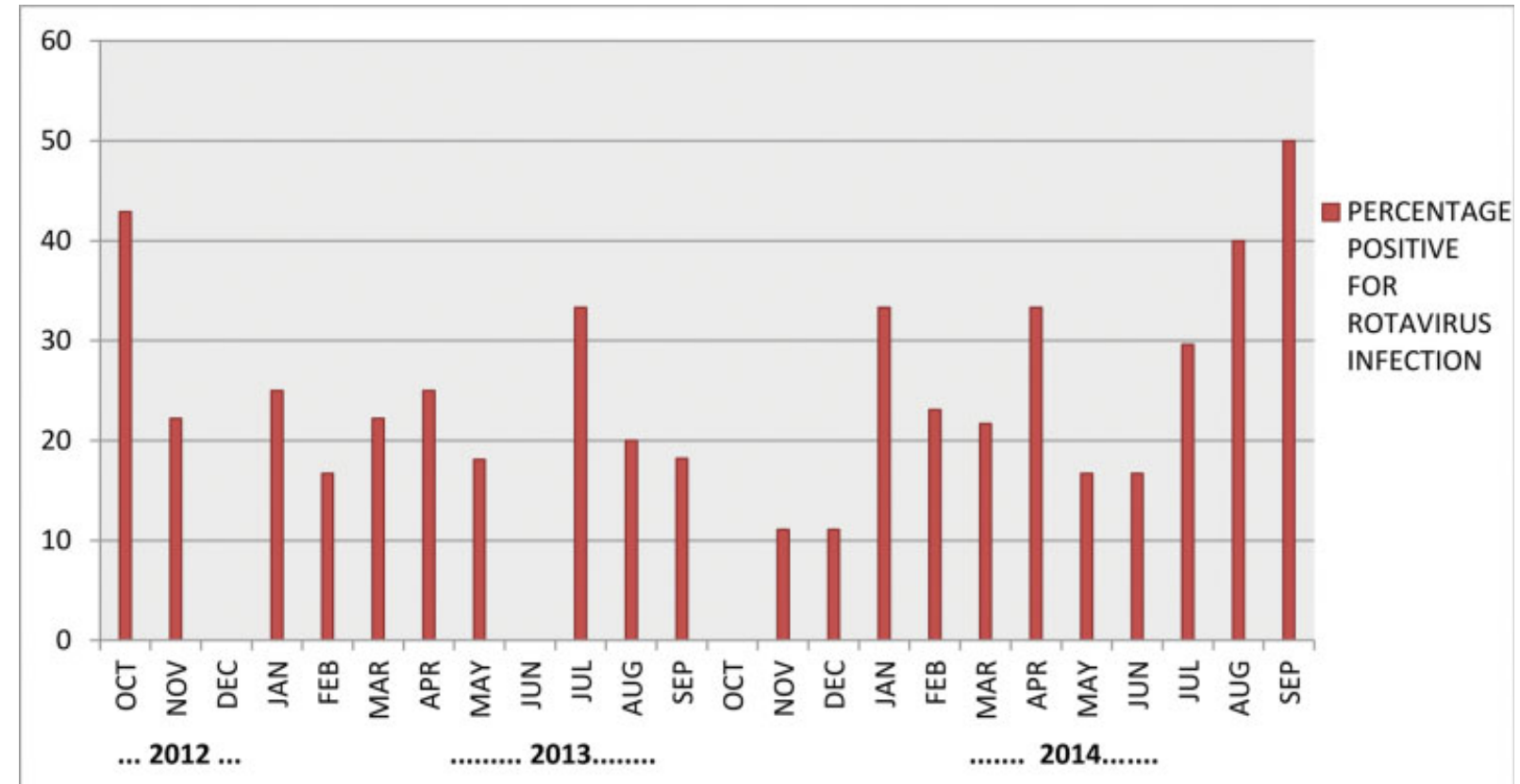

Fig. 3 Monthly rate of rotavirus positive samples among under 5 years children hospitalized of acute diarrhea from October 2012 to September 2014 in Ondo state, Nigeria.

months of October and November 2012 as well as January to May, and July to September 2013. Ten respondents were positive for RVA diarrhea during the dry season (October-March) while 8 participants were positive during the rainy season (AprilSeptember), representing a rate of 22.7 and $19.5 \%$, respectively. Between October 2013 and September 2014, RVA infection occurred consistently among the respondents from the month of November 2013 to September 2014 (-Fig. 3). Thirty-one respondents were positive for RVA diarrhea during the dry season (October-March) while 51 respondents were positive during the rainy season (April-September), representing 20.7 and $32.9 \%$, respectively. Statistically significant difference was not found in rate of RVA diarrhea during rainy and dry seasons of $2012 / 2013$ (chi-square $=0.131, p=0.717$ ) while a significant difference existed in rate of RVA infection during rainy season than dry season of 2013/2014 (chi-square $=5.802, p=0.016$ ) indicating a significant seasonal association and fluctuation. Overall, a significant seasonal association (chi-square $=4.113$; $p=0.043$ ) of RVA infection was found during the 2-year period. We observed fluctuations in the seasonal occurrence of RVA 
Table 3 Distribution of rotavirus infection by gender and locations of sample collection

\begin{tabular}{|c|l|l|l|l|l|l|l|}
\hline Akure & $\begin{array}{l}\text { Samples } \\
\text { tested }\end{array}$ & $\begin{array}{l}\text { Rotavirus } \\
\text { antigen }\end{array}$ & & $\begin{array}{l}\text { Samples } \\
\text { tested }\end{array}$ & $\begin{array}{l}\text { Rotavirus } \\
\text { antigen }\end{array}$ & Total \\
\hline & Total (\%) & $\begin{array}{l}\text { Positive } \\
\text { cases (\%) }\end{array}$ & $\begin{array}{l}\text { Negative } \\
\text { cases (\%) }\end{array}$ & Total (\%) & $\begin{array}{l}\text { Positive } \\
\text { cases (\%) }\end{array}$ & $\begin{array}{l}\text { Negative } \\
\text { cases (\%) }\end{array}$ & \\
\hline Gender: & & & & & & & Chi-square =0.712 \\
\hline Male & $131(62.4)$ & $43(32.8)$ & $88(67.2)$ & $109(60.6)$ & $15(13.8)$ & $94(86.2)$ & $p$-Value =0.399 \\
\hline Female & $79(37.6)$ & $30(38)$ & $49(62)$ & $71(39.4)$ & $12(16.9)$ & $59(83)$ & \\
\hline Total & $210(100)$ & $73(34.8)$ & $137(65.2)$ & $180(100)$ & $27(15)$ & $153(85)$ & \\
\hline$p$-Value & $\begin{array}{l}\text { Chi-square } \\
=0.576 ; \\
p=0.447\end{array}$ & & $\begin{array}{l}\text { Chi-square } \\
=0.333 ; \\
p=0.564\end{array}$ & & & \\
\hline
\end{tabular}

Table 4 Overall distribution of rotavirus infection by gender and age of children with diarrhea in Ondo state

\begin{tabular}{|c|c|c|c|c|c|c|c|}
\hline \multirow{2}{*}{$\begin{array}{l}\text { Age group } \\
(\mathrm{mo})\end{array}$} & \multicolumn{2}{|l|}{ Male } & \multicolumn{2}{|l|}{ Female } & \multicolumn{2}{|l|}{ Total } & \multirow[t]{2}{*}{$p$-Value } \\
\hline & No. tested (\%) & $\begin{array}{l}\text { No. (\%) } \\
\text { positive }\end{array}$ & No. tested (\%) & $\begin{array}{l}\text { No. (\%) } \\
\text { positive }\end{array}$ & No. tested (\%) & $\begin{array}{l}\text { No. (\%) } \\
\text { positive }\end{array}$ & \\
\hline $0-6$ & $37(15.4)$ & $16(43.2)$ & $33(22)$ & $16(48.5)$ & $70(18)$ & $32(45.7)$ & \\
\hline $7-12$ & $65(27)$ & $18(27.7)$ & $45(30)$ & $17(37.8)$ & $110(28.2)$ & $35(31.8)$ & \\
\hline $13-18$ & $51(21.3)$ & $12(23.5)$ & 25 (16.7) & $4(16)$ & 76 (19.5) & $16(21.1)$ & \\
\hline $19-24$ & $35(14.6)$ & $5(5.7)$ & $18(12)$ & $2(11.1)$ & $53(13.6)$ & $7(13.2)$ & \\
\hline $25-30$ & $28(11.7)$ & $4(14.3)$ & $10(6.7)$ & $1(10)$ & $38(9.7)$ & $5(13.2)$ & \\
\hline$>31$ & $24(10)$ & $3(12.5)$ & $19(12.7)$ & $2(4.7)$ & $43(11)$ & $5(11.6)$ & 0.00002 \\
\hline Total & 240 & $58(24.2)$ & 150 & $42(28)$ & 390 & $100(25.6)$ & 0.399 \\
\hline
\end{tabular}

Table 5 Distribution of rotavirus infection by season, among the study population in Ondo state Nigeria

\begin{tabular}{|c|c|c|c|c|c|c|c|}
\hline \multirow[t]{2}{*}{ Year } & \multirow[t]{2}{*}{ Period } & \multicolumn{2}{|c|}{$\begin{array}{l}\text { Dry season (October- } \\
\text { March) }\end{array}$} & \multicolumn{2}{|c|}{$\begin{array}{l}\text { Rainy season (April- } \\
\text { September) }\end{array}$} & \multirow[t]{2}{*}{ Total (\%) } & \multirow[t]{2}{*}{$p$-Value } \\
\hline & & $\begin{array}{l}\text { Positive } \\
\text { cases (\%) }\end{array}$ & $\begin{array}{l}\text { Negative } \\
\text { cases (\%) }\end{array}$ & $\begin{array}{l}\text { Positive } \\
\text { cases (\%) }\end{array}$ & $\begin{array}{l}\text { Negative } \\
\text { cases (\%) }\end{array}$ & & \\
\hline Year 1 & $\begin{array}{l}\text { October 2012- } \\
\text { September } 2013\end{array}$ & $\begin{array}{l}10 / 44 \\
(22.7)\end{array}$ & $\begin{array}{l}34 / 44 \\
(77.3)\end{array}$ & $\begin{array}{l}08 / 41 \\
(19.5)\end{array}$ & $\begin{array}{l}33 / 41 \\
(80.5)\end{array}$ & $\begin{array}{l}18 / 85 \\
(21.2)\end{array}$ & $\begin{array}{l}\text { Chi-square }=0.131 \\
p=0.717\end{array}$ \\
\hline Year 2 & $\begin{array}{l}\text { October 2013- } \\
\text { September } 2014\end{array}$ & $\begin{array}{l}31 / 150 \\
(20.7)\end{array}$ & $\begin{array}{l}119 / 150 \\
(79.3)\end{array}$ & $\begin{array}{l}51 / 155 \\
(32.9)\end{array}$ & $\begin{array}{l}104 / 155 \\
(67.1)\end{array}$ & $\begin{array}{l}82 / 305 \\
(26.9)\end{array}$ & $\begin{array}{l}\text { Chi-square }=5.807 \\
p=0.016\end{array}$ \\
\hline Total & $2 y$ & $\begin{array}{l}41 / 194 \\
(21.1)\end{array}$ & $\begin{array}{l}153 / 194 \\
(78.9)\end{array}$ & $\begin{array}{l}59 / 196 \\
(30.1)\end{array}$ & $\begin{array}{l}137 / 196 \\
(69.9)\end{array}$ & $\begin{array}{l}100 / 390 \\
(25.6)\end{array}$ & $\begin{array}{l}\text { Chi-square }=4.113 \\
p=0.043\end{array}$ \\
\hline
\end{tabular}

diarrhea in the study area, but taken together, infection rate was prevalent (30.1\%) in the rainy season (-Table 5).

\section{Discussion}

United Nations Millennium Development Goal 4 was meant to reduce the mortality rate of children under 5 years of age by two-thirds in 2015 . However, this milestone has not been reached in 2020, since diarrhea continue to be a major global cause of morbidity and mortality among children, particularly in low-resource settings. ${ }^{23}$ RVA is responsible for nearly 260 million diarrhea episodes and one-third of all diarrhea-associated mortality in 2016. ${ }^{24}$ This development goal will only be reached by worldwide adoption of vaccination to preventing RVA, a single viral pathogen responsible for more acute diarrhea hospitalizations, severe dehydration, and rapid death among children under 5 years of age, particularly in developing countries of sub-Saharan Africa and South Asia. 
For successful implementation of a vaccination program, a pool of baseline data is required as a framework. RVA diarrhea is not often a reportable disease, and laboratory testing for RVA infection is not always performed during care for acute gastroenteritis. Hence, in some parts of Nigeria, particularly Ondo state, there is currently a paucity of data on the epidemiology and the molecular identities of RVA etiology of infantile gastroenteritis. It was paramount to fill these existing vacuums by determining the epidemiology of group A rotavirus gastroenteritis among children aged below 5 years, as one of the necessary conditions before instituting a vaccine campaign, particularly in Ondo state where diarrhea illness is a significant contributor to the hospitalization and mortality of infants. ${ }^{13,17,20}$

Significant proportions (25.6\%) of children that presented in the hospital with severe diarrhea in this research were found to be infected with RVA. As reportedly found in some parts of Nigeria ${ }^{25-27}$ and other African countries of Sierra Leone, Burkina Faso, Cameroon, and Ghana, ${ }^{28-31}$ this research indicate that RVA continues to be an unabated cause of severe acute infantile diarrhea in Nigeria.

The highest RVA infection rate of $45.7 \%$ was found in children aged 0 to 6 months, followed by children between 7 and 12 months. This finding is similar to previous reports from Nigeria, ${ }^{25,27}$ Ghana, ${ }^{32}$ Kenya, ${ }^{33}$ Burkina Faso, ${ }^{29}$ Sierra Leone, ${ }^{34}$ Iran, and India, ${ }^{35}$ thereby corroborating the submission of Steele et al and Bilcke et al that rotavirus infection occurs in early childhood. ${ }^{36,37}$ This study indicated that the disease burden in this state is highest in the most vulnerable age group 0 to 6 months. However, this age group prevalence slightly contrasts the previous report of RVA prevalence in 7 to 12 months old boys in Jos Nigeria, ${ }^{38}$ and the submission of Parashar et al as well as Dennehy of more prevalent RVA infections in children aged between 9 and 15 months in the developed countries. ${ }^{39,40}$ Statistically, RVA infection varied significantly with age. The higher infection rate was found in children below 18 months old than in those 18 months and above, thereby substantiating the previous studies in Nigeria and other nations. ${ }^{14,33,41,42}$

In tandem with the recent reports from Benin City Nigeria and Kenya, more males were enrolled than females in this study, but the rate of infection was higher in the female children, though the difference was not significant. ${ }^{16,43}$ However, in some other studies from Nigeria, a higher rate was found of RVA infection in males than female children. $^{27,38,44}$

Source of drinking water remains a paramount variable in the transmission of RVA. In this study, the highest percentage of respondents with RVA diarrhea obtained drinking water from wells, as well as tap water and well water combined, as previously reported. ${ }^{38}$ These may be attributed to contamination of shallow communal wells by urban runoffs, use of contaminated utensils for fetching water, use of wells for both laundry/drinking purposes, and poor condition of the majority of the wells. Furthermore, RVA is a significant waterborne pathogen associated with diarrhea, having persistence in water supplies, resistant to chlorine disinfection, and having infective low inoculum size of 1 to 100 virions. $^{45}$
It was observed that a considerable number of respondents that strictly utilized tap water for drinking also had RVA diarrhea as earlier reported by Olusanya and Taiwo in Ile-Ife, Nigeria and corroborated by Leite et al that good water supply and sanitation were not likely to reduce RVA infection. ${ }^{46,47}$ This may be attributable to either the inadequate levels of chlorine $(0-0.05 \mathrm{mg} / \mathrm{L}$ in the water) or to contamination of the water depository well, as previously reported in a waterborne outbreak. ${ }^{48}$

Evaluation of type of occupation of the parents as a risk factor for infection in the children shows that the children whose parents were traders, civil servants, and selfemployed had the highest rate of RVA shedding, while children of the unemployed and those who were subsistence farmers had the lowest incidence of RVA infection. These further corroborate previous studies that reported RVA diarrhea as prevalent in children of Nigerian market women. ${ }^{49}$ In consonant with the report of Omatola et al, a statistically significant association was not found $(p=0.072$ ) between infection by RVA and occupation of respondents' parents, thereby indicating that these children were susceptible to RVA infection irrespective of their socioeconomic backgrounds. ${ }^{50}$

Consistent with previous studies conducted in Uganda, Ghana, Nigeria, Sierra Leone, Burkina Faso, Spain, Cameroon, Iran, Lao, and other countries, ${ }^{27,29,31,51-56}$ diarrhea was the prominent sign of RVA infection followed by fever, vomiting, and dehydration, although Junaid et al reported more participants with vomiting than fever in their study group. ${ }^{38}$ However, the frequency of diarrhea observed in this research was higher than the report of Junaid et al from Nigeria. ${ }^{38}$

A high percentage $(80 \%)$ of the children presented with vomiting and the average duration of vomiting was 3 days, while within a 24-hour period an average child with RVA diarrhea vomited 4.5 times, thereby corroborating a previous report. ${ }^{57}$ Furthermore, in contrast to reports from Canada and France, a significant relationship was not found between infection by RVA and vomiting as well as the presence of high-grade fever. ${ }^{58,59}$ As opposed to previously held belief of high fever and sporadic vomiting in RVA infection, this finding suggests that less vomiting and mild fever does not rule out RVA infection. As previously reported, characteristic vomiting combined with explosive diarrhea episodes of RVA gastroenteritis were responsible for causing rapid dehydration. ${ }^{60}$ It was observed in this study that $41 \%$ of the children were severely dehydrated while $19 \%$ were comatose and required emergency intravenous rehydration and oxygen resuscitation, although the significant relationship was not found between infection caused by RVA and dehydration in the children.

The development of URTI was insignificantly related to RVA infection in the children. However, the observation of the presence of respiratory symptoms in $19 \%$ of the cases is also in agreement with earlier reports that indicated the presence of various upper and lower respiratory infections during RVA illness. ${ }^{61}$ It may be as a result of chance due to collection of samples during the peak period of respiratory infections as previously suggested. ${ }^{62}$ 
Generally, this research indicated that infection by RVA occurred all through the year with a similar trend of the cluster in January, February, March, April, and May, as well as monthly peaks in January, April, July, August, September, and November during the 2-year period. A significant seasonal association was observed between RVA infection during the rainy season than a dry season of 2013/2014. Conversely, no significant difference in the rate of RVA diarrhea during the rainy and dry seasons of 2012/2013 was observed when there was generally low level of rainfall. Overall, a significant seasonal association of RVA infection was found in the 2-year period with fluctuations in the seasonal occurrence of RVA diarrhea as infection rate was prevalent in the rainy season. These observations slightly contrast previous reports from Northern Nigeria and Burkina Faso, where higher prevalence during dry months was recorded. ${ }^{27,63}$ The difference may be attributed to the impact of the breakdown of sanitation during the rainy season and the contamination of potable water sources by urban runoffs and leachates.

The observed RVA infection rate $(25.6 \%)$ in this study is less than the predicted RVA diarrhea-associated rate of $40 \%$ but remained within the observed constant limit of $25 \%$ over the past three decades. ${ }^{64,65}$ Considering previous hospitalbased studies in Nigeria, $25.6 \%$ in this research is lower than the $55.9 \%$ reported for Ilorin Kwara State, Nigeria. ${ }^{66}$ However, the rate is similar to recent hospital-based reports of $25.8 \%$ in Lagos, as well as $25.5 \%$ in Sokoto Nigeria. ${ }^{67,68}$ Conversely, the $25.6 \%$ is higher than a rate of $7.7 \%$ obtained in separate community-based studies in Ibadan, the $9 \%$ reported in Northwestern Nigeria, the $11.9 \%$ in Maiduguri, as well as the $13.8 \%$ for Jos Plateau state, Nigeria. ${ }^{25,27,38,69}$

As noted in previous studies, the differences in the prevalence recorded by different investigators were attributed to disintegration of viral particles, hence insufficient antigen in the specimen due to differences in time of sample collection, prolonged storage and poor storage facility, transportation to overseas laboratory facility for analysis, method of screening samples, or the geographical location of the study. ${ }^{27,70}$ However, these challenges were significantly overcome in this study as samples were collected within two RVA seasons and promptly tested for RVA at the Virology Laboratory of the University of Ibadan within the geographical location of the study, thereby maximizing the samples' integrity.

Outside Nigeria, many recent reports in Africa have indicated fluctuations in the prevalence of RVA diarrhea. EnweronuLaryea et al reported $48.2 \%$ among under-five children in Southern Ghana, Ouédraogo et al reported 63.5\% in Burkina Faso, Jere et al reported 35\% in Sierra Leone while Agutu et al found $31.5 \%$ in Kenyan children. ${ }^{31,43,71,72}$ Curiously, as high as the prevalences were, none of these previous studies reported mortality rates in their respective study locations, either to assess the need for and/or to assess the impact of vaccination.

Most importantly, the disease prevalence in this present study is sufficient for a need to institute RVA immunization program in the state, particularly, where a case fatality rate of $1 / 17$ (5.9\%), a group mortality rate of $1 / 45(2.2 \%)$ in children 7 to 12 months old in Akure, and an overall crude mortality rate of $1 / 100(1 \%)$ was recorded. This is the first research reporting RVA associated mortality in the state. Contrary to the earlier submission that 1 in every 205 children hospitalized of RVA diarrhea will die of the disease, ${ }^{73}$ our observation during the 2-year study period shows that 1 in 100 RVA positive children died of the disease. Although this is lower than the 50\% mortality reported in children 3 to 23 months of age in Bangladesh, ${ }^{74}$ it is, however, a considerable percentage in the Nigerian settings, thereby stressing the need for vaccine introduction.

\section{Conclusion}

RVA diarrheal disease occurred among under-five children in Ondo state with a prevalence of $25.6 \%$, predominantly in the females, and in children between 0 and 6 months. Statistically, RVA infection was significantly higher in children aged below 18 months than in children 18 months and above. Therefore, this may help in determining the optimal period/ schedule of any immunization program that may be instituted to mitigate this disease. The high prevalence and mortality recorded are strong justifications to implement a RVA vaccination program in Nigeria. A significant seasonal association of RVA infection was found in the 2-year period with fluctuations in the seasonal occurrence of RVA diarrhea as infection rate was prevalent in the rainy season. It is pertinent to urgently improve the provision and access to piped water, public health enlightenment, education of parents regarding the provision of home-cooked balanced meals, and standard hygiene practices. Refuse collection and disposal must be strengthened in the study areas, as very many households dispose of refuse inappropriately in unauthorized dump sites that may give rise to leachates and runoffs which may potentially contaminate sources of drinking water.

Note

This publication derived from the PhD Research Thesis of M.O.B. on molecular epidemiology of group A rotavirus among children with gastroenteritis in Ondo state, Nigeria.

\section{Conflict of Interest}

None declared.

\section{Acknowledgments}

We sincerely appreciate the children who participated in this study, and the parents who consented to provide stool specimens-all Doctors and Nurses at the Children Emergency Wards of the Federal Medical Centre Owo: Dr. A.O. Alonge, Dr. Oluloro, Dr. Ayun, and Dr. Damilotun; at the State Specialists Hospital Akure: Dr. A. Ikuomola, Dr. Noel, Dr. (Mrs) Olubosede, and Dr. (Mrs) Akeredolu; at the Mother and Child Hospital Akure: Dr. (Mrs) Oluwayemi, Dr. Alonge, Dr. Ajayi, and others. For technical support, we thank Dr. (Mrs) Adedayo Faneye, Mr. Babatunde Olusola, Mr. Maxwell Ibe, Dr Adebowale Olayinka and Mr. Bolu Popoola of the Department of Virology, University of Ibadan. 


\section{References}

1 Greenberg HB, Estes MK. Rotaviruses: from pathogenesis to vaccination. Gastroenterology 2009;136(06):1939-1951

2 Estes MK, Greenberg HB. Rotaviruses. In: Knipe DM, Howley PM, et al, eds. Fields Virology, 6th ed. Philadelphia, PA: Wolter Kluwer Health/Lippincott Williams \& Wilkins; 2013:1347-1401

3 Mihalov-Kovács E, Gellért Á, Marton S, et al. Candidate new rotavirus species in sheltered dogs, Hungary. Emerg Infect Dis 2015;21(04):660-663

4 Bányai K, Kemenesi G, Budinski I, et al. Candidate new rotavirus species in Schreiber's bats, Serbia. Infect Genet Evol 2017;48:19-26

5 Saif LJ, Jiang B. Nongroup A rotaviruses of humans and animals. Curr Top Microbiol Immunol 1994;185:339-371

6 Doan LT, Okitsu S, Nishio O, Pham DT, Nguyen DH, Ushijima H. Epidemiological features of rotavirus infection among hospitalized children with gastroenteristis in Ho Chi Minh City, Vietnam. J Med Virol 2003;69(04):588-594

7 Santos N, Soares CC, Volotão EM, Albuquerque MC, Hoshino Y. Surveillance of rotavirus strains in Rio de Janeiro, Brazil, from 1997 to 1999. J Clin Microbiol 2003;41(07):3399-3402

8 Parashar UD, Burton A, Lanata C, et al. Global mortality associated with rotavirus disease among children in 2004. J Infect Dis 2009; 200(Suppl 1):S9-S15

9 Tate JE, Burton AH, Boschi-Pinto C, Steele AD, Duque J, Parashar UDWHO-coordinated Global Rotavirus Surveillance Network. 2008 estimate of worldwide rotavirus-associated mortality in children younger than 5 years before the introduction of universal rotavirus vaccination programmes: a systematic review and meta-analysis. Lancet Infect Dis 2012;12(02):136-141

10 GBD 2016 Causes of Death Collaborators. Global, regional, and national age-sex specific mortality for 264 causes of death, 19802016: a systematic analysis for the Global Burden of Disease Study 2016. Lancet 2017;390(10100):1151-1210

11 United States Agency for International Development, World Health Organization, and United Nations Children's Fund Diarrhoea treatment guidelines including the new recommendations for the use of ORS and zinc supplementation for clinic-based healthcare workers. 2005. Available at: www.mostproject.org/ZINC/Zinc Updates_Apr05/Diarrhoea guidelines.pdf. Accessed September 17, 2020

12 Tate JE, Burton AH, Bosch-Pinto C, Parashar UD. World Health Organization- Coordinated Global Rotavirus Surveillance Network. Global, regional, and national estimates of rotavirus mortality in children. Clin Infect Dis 2016;62(S2)S96-S105

13 Lang DR, Glass RI, Compans RW. Summary of the Fifth Rotavirus Vaccine Workshop. J Infect Dis 1996;174(Suppl 1):S3-S4

14 Audu R, Omilabu SA, de Beer M, Peenze I, Steele AD. Diversity of human rotavirus VP6, VP7, and VP4 in Lagos State, Nigeria. J Health Popul Nutr 2002;20(01):59-64

15 Abiodun PO, Omoigberale A. Prevalence of nosocomial rotavirus infection in hospitalized children in Benin City, Nigeria. Ann Trop Paediatr 1994;14(01):85-88

16 Iyoha O, Abiodun PO. Human rotavirus genotypes causing acute watery diarrhea among under-five children in Benin City, Nigeria. Niger J Clin Pract 2015;18(01):48-51

17 Jinadu MK, Olusi SO, Agun JI, Fabiyi AK. Childhood diarrhoea in rural Nigeria. I. Studies on prevalence, mortality and socioenvironmental factors. J Diarrhoeal Dis Res 1991;9(04):323327

18 N.P.C. Population and Housing Census National Population Commission (NPopC). 2006

19 United Nations Children Fund Levels and Trends in Child Mortality-Report 2010 Estimates Developed by the United Nations Interagency Group for Child Mortality Estimation United Nations Children's Fund. 2010

20 Ondo State Bureau of Statistics Report of Integrated Household Survey in Ondo state 2011 Ondo State Bureau of Statistics Akure /NSDP/SRF/World Bank. 2012:1-70
21 World Health Organization Generic protocol for (i) a hospitalbased surveillance to estimate the burden of rotavirus gastroenteritis in children and (ii) a community-based survey on utilization of health care services for gastroenteritis in children Geneva Field test version. 2002; Document WHO/V\&B/02.15

22 Babalola MO, Odaibo GN, Olaleye OD, Alonge AO. Enteric adenovirus and norovirus gastroenteritis among under- 5 years children in Owo, Ondo State, Nigeria. Br J Med Med Res 2015;9(08):1-9

23 Troeger C, Forouzanfar M, Rao PC, et al; . Estimates of global, regional, and national morbidity, mortality, and aetiologies of diarrhoeal diseases: a systematic analysis for the Global Burden of Disease Study 2015. Lancet Infect Dis 2017;17(09):909-948

24 Troeger C, Khalil IA, Rao PC, et al. Rotavirus vaccination and the global burden of rotavirus diarrhea among children younger than 5 years. JAMA Pediatr 2018;172(10):958-965

25 Adah MI, Rohwedder A, Olaleyle OD, Werchau H. Nigerian rotavirus serotype G8 could not be typed by PCR due to nucleotide mutation at the 3 ' end of the primer binding site. Arch Virol 1997; 142(09):1881-1887

26 Adah MI, Wade A, Taniguchi K. Molecular epidemiology of rotaviruses in Nigeria: detection of unusual strains with G2P[6] and G8P[1] specificities. J Clin Microbiol 2001;39(11):3969-3975

27 Aminu M, Esona MD, Geyer A, Steele AD. Epidemiology of rotavirus and astrovirus infections in children in northwestern Nigeria. Ann Afr Med 2008;7(04):168-174

28 Asmah RH, Green J, Armah GE, et al. Rotavirus G and P genotypes in rural Ghana. J Clin Microbiol 2001;39(05):1981-1984

29 Bonkoungou IJO, Sanou I, Bon F, et al. Epidemiology of rotavirus infection among young children with acute diarrhoea in Burkina Faso. BMC Pediatr 2010;10:94

30 Ayuk TB, Nyobe EC, Nchung JA, et al. Prevalence of diarrhoea and associated risk factors among children under-five years of age in Efoulan health district- Cameroon, sub- Saharan Africa. MOJ Public Health. 2018;7(06):259-264

31 Jere KC, Sawyerr T, Seheri LM, et al. A first report on the characterization of rotavirus strains in Sierra Leone. J Med Virol 2011;83(03):540-550

32 Armah GE, Pager CT, Asmah RH, et al. Prevalence of unusual human rotavirus strains in Ghanaian children. J Med Virol 2001; 63(01):67-71

33 Abebe A, Teka T, Kassa T, et al. Hospital-based surveillance for rotavirus gastroenteritis in children younger than 5 years of age in Ethiopia: 2007-2012. Pediatr Infect Dis J 2014;33(Suppl 1): S28-S33

34 François PR, de Villiers FPR, Sawyerr TN, de Villiers GK. The incidence and clinical presentation of infantile rotavirus diarrhea in Sierra Leone. S Afr Med J 2009;99:4

35 Kazemi A, Tabatabaie F, Agha-Ghazvini MR, Kelishadi R. The role of Rotavirusin acute Pediatric diarrhea in Isfahan, Iran. Pak J Med Sci 2006;22(03):282-285

36 Steele AD, Nimzing L, Peenze I, et al. Circulation of the novel G9 and G8 rotavirus strains in Nigeria in 1998/1999. J Med Virol 2002;67(04):608-612

37 Bilcke J, Van Damme P, Van Ranst M, Hens N, Aerts M, Beutels P. Estimating the incidence of symptomatic rotavirus infections: a systematic review and meta-analysis. PLoS One 2009;4; (06): 66060

38 Junaid SA, Umeh C, Olabode AO, Banda JM. Incidence of rotavirus infection in children with gastroenteritis attending Jos university teaching hospital, Nigeria. Virol J 2011;8:233

39 Parashar UD, Glass RI. Viral causes of gastroenteritis. In: Desselberger U, Gray J, ed. Viral Gastroenteritis. Vol. 9. Amsterdam: Elsevier; 2003:9-21

40 Dennehy PH. Rotavirus vaccines: an overview. Clin Microbiol Rev 2008;21(01):198-208

41 Gomwalk NE, Gosham LT, Umoh UJ. Rotavirus gastroenteritis in pediatric diarrhoea in Jos, Nigeria. J Trop Pediatr 1990;36(02): $52-55$ 
42 Alam MM, Khurshid A, Shaukat S, et al. Epidemiology and genetic diversity of rotavirus strains in children with acute gastroenteritis in Lahore, Pakistan. PLoS One 2013;8(06):e67998

43 Agutu MT, Ongus J, Kombich J, et al. Prevalence and genetic diversity of rotavirus infection in children with acute gastroenteritis in a hospital setting, Nairobi Kenya in post vaccination era: a cross-sectional study. Pan Afr Med J 2017;26:38

44 Pennap G, Peenze I, De Beer MKwaga JKP, et al; VP6 subgroup and VP7 serotype of human rotavirus in Zaria, northern Nigeria. J Trop Pediatr 2000;46(06):344-347

45 World Health Organization Guidelines for Drinking-water Quality. 2011. Available at: http://www.who.int/water_sanitation_health/ publications/2011/dwq chapters/en/index.html.Accessed February2, 2013

46 Olusanya O, Taiwo O. Rotavirus as an aetiological agent of acute childhood diarrhoea in Ile-Ife, Nigeria. East Afr Med J 1989;66 (02):100-104

47 Leite JPG, Alfieri AA, Woods PA, Glass RI, Gentsch JR. Rotavirus G and P types circulating in Brazil: characterization by RT-PCR, probe hybridization, and sequence analysis. Arch Virol 1996;141 (12):2365-2374

48 Koroglu M, Yakupogullari Y, Otlu B, et al. A waterborne outbreak of epidemic diarrhea due to group A rotavirus in Malatya, Turkey. New Microbiol 2011;34(01):17-24

49 Omokhodion FO, Oyemade A, Sridhar MK, Olaseha IO, Olawuyi JF. Diarrhoea in children of Nigerian market women: prevalence, knowledge of causes, and management. J Diarrhoeal Dis Res 1998; 16(03):194-200

50 Omatola CA, Olusola BA, Odaibo GN. Rotavirus infection among under five children presenting with gastroenteritis in Ibadan, Nigeria. Arch Basic and Appl Med 2016;3:3-8

51 Nakawesi JS, Wobudeya E, Ndeezi G, Mworozi EA, Tumwine JK. Prevalence and factors associated with rotavirus infection among children admitted with acute diarrhea in Uganda. BMC Pediatr 2010;10:69

52 Binka FN, Anto FK, Oduro ARNavrongo Rotavirus Research Group, et al; Incidence and risk factors of paediatric rotavirus diarrhoea in northern Ghana. Trop Med Int Health 2003;8(09): 840-846

53 Sénécal M, Brisson M, Lebel MHMIRAGE study group, et al; Measuring the impact of rotavirus acute gastroenteritis episodes (MIRAGE): a prospective community-based study. Can J Infect Dis Med Microbiol 2008;19(06):397-404

54 Aloun DS, Nyambat B, Phetsouvanh R, et al. Rotavirus diarrhoea among children aged less than 5 years at Mahosot Hospital, Vientiane, Lao PDR. Vaccine 2009;27(Suppl 5):F85-F88

55 Gimenez-Sanchez F, Delgado-Rubio A, Martinon-Torres F, Bernaola-Iturbe ERotascore Research Group. Multicenter prospective study analysing the role of rotavirus on acute gastroenteritis in Spain. Acta Paediatr 2010;99(05):738-742

56 Najafi A, Kargar M, Jafarpour T. Burden and typing of rotavirus group a in children with acute gastroenteritis in Shiraz, southern Iran. Iran Red Crescent Med J 2012;14(09):531540
57 Uzoma EB, Chukwubuikem C, Omoyibo E, Tagbo O. Rota virus genotypes and the clinical severity of diarrhoea among children under 5 years of age. Niger Postgrad Med J 2016;23(01):1-5

58 Rivest P, Proulx M, Lonergan G, Lebel MH, Bédard L. Hospitalisations for gastroenteritis: the role of rotavirus. Vaccine 2004;22 (15-16):2013-2017

59 Salinas B, Pérez Schael I, Linhares AC, et al. Evaluation of safety, immunogenicity and efficacy of an attenuated rotavirus vaccine, RIX4414: a randomized, placebo-controlled trial in Latin American infants. Pediatr Infect Dis J 2005;24(09):807-816

60 Mast TC, DeMuro-Mercon C, Kelly CM, Floyd LE, Walter EB. The impact of rotavirus gastroenteritis on the family. BMC Pediatr 2009;9(11):11

61 Zheng BJ, Chang RX, Ma GZ, et al. Rotavirus infection of the oropharynx and respiratory tract in young children. J Med Virol 1991;34(01):29-37

62 Dodet B, Heseltine E, Saliou P. Rotaviruses in human and veterinary medicine. Trends Microbiol 1997;5(05):176-178

63 Nitiema LW, Nordgren J, Ouermi D, et al. Burden of rotavirus and other enteropathogens among children with diarrhea in Burkina Faso. Int J Infect Dis 2011;15(09):e646-e652

64 Parashar UD, Gibson CJ, Bresee JS, Glass RI. Rotavirus and severe childhood diarrhea. Emerg Infect Dis 2006;12(02):304-306

65 Waggie Z, Hawkridge A, Hussey GD. Review of rotavirus studies in Africa: 1976-2006. J Infect Dis 2010;202:S23-S33

66 Odimayo MS, Olanrewaju WI, Omilabu SA, Adegboro B. Prevalence of rotavirus-induced diarrhea among children under 5 years in Ilorin, Nigeria. J Trop Pediatr 2008;54(05):343-346

67 Ayolabi Cl, Ojo DA, Armah GE. Electropherotypes and G-types of group A rotaviruses detected in children with diarrhea in Lagos, Nigeria. ISRN Virol 2013. Doi: 10.5402/2013/179871

68 Alkali BR, Daneji AI, Magaji AA, Bilbis LS. Clinical symptoms of human rotavirus infection observed in children in Sokoto, Nigeria. Adv Virol 2015;2015;. Doi: 10.1155/2015/890957

69 Oyejide CO, Fagbami AH. An epidemiological study of rotavirus diarrhoea in a cohort of Nigerian infants: II. Incidence of diarrhoea in the first two years of life. Int J Epidemiol 1988;17(04):908-912

70 Centers for Disease Control and Prevention (CDC). Rotavirus surveillance-worldwide, 2001-2008. MMWR Morb Mortal Wkly Rep 2008;57(46):1255-1257

71 Enweronu-Laryea CC, Sagoe KW, Damanka S, Lartey B, Armah GE. Rotavirus genotypes associated with childhood severe acute diarrhoea in southern Ghana: a cross-sectional study. Virol J 2013; $10: 287$

72 Ouédraogo N, Kaplon J, Bonkoungou IJO, et al. Prevalence and genetic diversity of enteric viruses in children with diarrhea in Ouagadougou, Burkina Faso. PLoS One 2016;11(04):e0153652

73 Glass RI, Kilgore PE, Holman RC, et al. The epidemiology of rotavirus diarrhea in the United States: surveillance and estimates of disease burden. J Infect Dis 1996;174(Suppl 1):S5-S11

74 Satter SM, Gastanaduy PA, Islam K, et al. Hospital-based surveillance for rotavirus gastroenteritis among young children in Bangladesh: defining the potential impact of a rotavirus vaccine program. Pediatr Infect Dis J 2017;36(02):168-172 